JURAJ VACULÍK, Ph.D.

E-mail: juvac@fpedas.uniza.sk

IVAN MICHÁLEK, Eng.

E-mail: imichalek@centrum.sk

PETER KOLAROVSZKI, Eng.

E-mail: kolarovszki@fpedas.uniza.sk

University of Žilina, Faculty of Operation and Economics of

Transport and Communications

Department of Communications

Univerzitná 1, 01026 Žilina, Slovak Republic
Information and Communication Technology

Review

Accepted: Feb. 15, 2008

Approved: Dec. 22, 2008

\title{
PRINCIPLES OF SELECTION, IMPLEMENTATION AND UTILIZATION OF RFID IN SUPPLY CHAIN MANAGEMENT
}

\begin{abstract}
The paper deals with RFID (Radio Frequency Identification) implementation and utilization within supply chain management and also includes the economic feasibility of rolling out RFID. The members of the supply chain networks - suppliers, manufacturers and distributors - will operate independently from one another and according to their own agendas. This type of unmanaged network, however, results in inefficiencies. The manufacturer might have a goal of maximizing production in order to minimize unit costs. Clearly, all members of the supply chain stand to gain by coordinating their efforts to improve efficiency and overall supply chain performance. This article is divided into three parts: Supply chain, Economic feasibility of rolling out RFID and Processes of Supply chain management.
\end{abstract}

\section{KEY WORDS}

RFID, supply chain management, processes, implementation

\section{INTRODUCTION}

Supply chain management is the combination of process and information technology to integrate the members of the supply chain - suppliers, manufacturers and distributors - into a whole. It includes demand forecasting, material requisitions; order processing, order fulfilment, transportation services, receiving, invoicing, and payment processing. Supply chain managers already have many tools to wield at these problems. RFID will be a new tool and will offer an unprecedented ability for supply chain members to coordinate their activities. In managing supply chains, the information collected by RFID networks will become inputs to the fundamental decision:

- location: of facilities and sourcing points,

- production: what to produce and in which facilities,
- inventory: how much to order, when to order and safety stocks,

- transportation: mode of transport, shipment size, routing and scheduling.

\section{SUPPLY CHAIN}

In the days of supply chains without RFID technology, SCM, Supply Chain Planning (SCP), Supply Chain Execution (SCE), and Supply Chain Optimization $S C O$ ) were discussed and debated in the growing global network of supply chains. Also discussed and debated were Supply Chain Visibility (SCV), supply Chain Process Management (SCPM), Supply Chain Event Management (SCEM), and Supply Chain performance Management ( $S C p M$ ). We have entered the age of supply chains with RFID technology.

Supply chain with RFID technology is a global network of integration hubs of suppliers and clients that create, track, and deliver RFID-tagged finished products manufactured from raw materials and semi-finished parts to multiple destinations from multiple supply sources. A supplier may serve as the primary or coordinating supplier or the secondary supplier depending on others for the raw materials and semi-finished product parts.

A client may be a retailer, wholesaler, warehouse manager, manufacturer, or even a senior executive. The client may serve as the primary or coordinating client or the secondary client depending on other clients to receive the finished products in the right quantities with the right specifications at the right time at the right locations.

Each player has a role in the physical movement of materials and products from one point to another in the supply chain. The supply chain, as a whole, in- 
volves all facilities, functions, and activities in manufacturing the product, coding basic information in RFID tags, reading and writing in real-time tracking activities of the product in the RFID technology infrastructure, and delivering the product to the customer who initiated the order. This infrastructure is integrated with back-end systems such as ERP, SCM, virtualized databases, legacy systems, and new wrap-up systems.

Figure 1 - Supplier and customer interaction gives an example of how a supplier is related to or coordinates with other suppliers in a hierarchy of different levels. It begins with a supply chain at level 0 receiving the semi-finished products from the two supply chains at level 1 , one of which receives another semi-finished product from a third supply chain at level 2 , that in turn gets raw materials from the fourth supply chain at level 3 . The other supply chain at level 1 transports semi finished products to the supply chain at level 0 and finished products to a customer at level 1 . The level 1 customer that bypasses the level 0 supply chain to get the finished products from level 1 supply chain can deliver the products to Customers at lower levels. One of these customers can receive a batch of finished products from level 3 supply chain that also sends semi-finished products to level 0 supply chain.

Whereas level 0 supply chain focuses on, say, consumer packaged goods, the supply chains at other levels may focus on one of the three models of consumer packaged goods, mass production or mass customization, or a combination of two or more models. The interaction of suppliers and customers gets more complex as the supply chains become more global and collaboratively communicate with one another over the Web in a standard way that spans interorganizational and geographical boundaries. [1]

One way of handling the complex interaction between the customers and suppliers is to manage the business processes of the supply chain interactions.

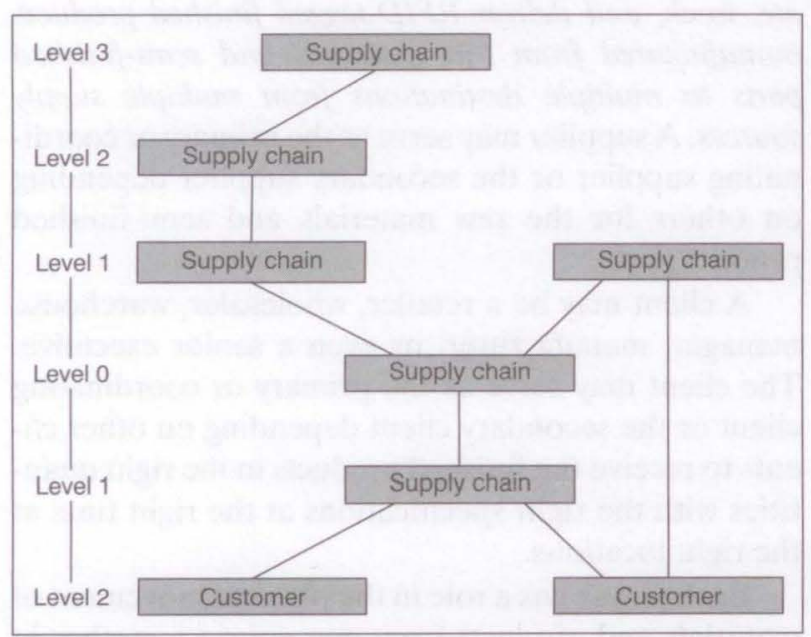

Figure 1 - Supplier and customer interaction [1]
This can be accomplished through SCM that involves business processes of planning, coordinating, integrating, managing, scheduling, controlling, producing, tracking, and delivering the product throughout the RFID technology infrastructure. SCM aims at increasing the product visibility and speed via optimizing techniques used in the RFID infrastructure to read and write tracking information in real-time while integrating internal supply chain resources with external resources.

Business processes, however, are one part of SCM strategy. Management techniques and product visibility make up the other parts of the SCM. To better visualize the SCM, a conceptual model of SCM is built as shown in Figure 2, which says that SCM starts with visibility and speed of the items as the base for the model. To make the base work, we move up to the next layer which focuses on techniques used in RFID technology infrastructure. How the techniques are selected and chosen depends on business processes in the third layer. What business processes to use and implement depends largely on what management philosophy and style is used to run the supply chain organization.

Associated with SCM is the Supply chain planning (SCP) with RFID technology that involves the collaboration of demand and supply using RFID infrastructure to track multiple products at various points in the supply chain for delivery of the items to satisfy the demands of multiple customers. It is often involved with planning, network planning, capacity planning, demand planning, manufacturing resources, scheduling, distribution, and deployment resources.

More important is the forecasting of demand and supply changes while the executives are involved with managers on planning production. SCP is concerned with creating a set of suppliers in response to buyer forecasts, and with coordinating RFID technology assets to optimize the delivery of products in order to balance demand and supply at a given point of time.

Let us take a quick look at SCE, SCO, SCV, and SCPM.

Supply chain executive (SCE) provides a framework of applications that enable procurement and supply of products through RFID technology infrastructure integrated with the enterprise integration hub of SCM systems, ERP systems, virtualized databases, legacy

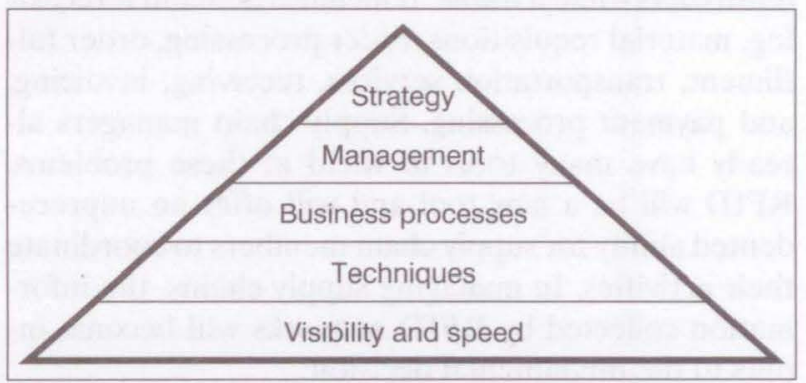

Figure 2 - Supply chain management conceptual model [1] 
systems, Manufacturing Execution Systems (MESs), Warehouse Management Systems (WMSs), Transportation Management Systems (TMSs), and middleware technologies. The RFID infrastructure is a possible replacement for the Supply Chain Inventory Visibility (SCIV) system as RFID tracking activities in real-time can contribute to increasing the visibility of the products being tracked.

Supply chain optimization (SCO) with RFID technology aims at the best operating performance while optimizing schedules to reduce manufacturing and logistics bottlenecks in the supply chain. It employs the use of operations research techniques to maximize or minimize item tracking, production, and transportation capacity.

Supply chain visibility (SCV) is a means of capturing and analyzing the data from logistics activities to enhance the visibility of supply chains with RFID technology. RFID infrastructure allows tracking and tracing inventory globally on a line-item level, as well as case or pallet level. It also permits sending alerts when events deviate from expectations or unforeseen incidents.

The visibility of orders and shipments on a real-time basis as provided by the infrastructure and associated enterprise integration hubs gives enterprises advance knowledge of not only when the products will arrive, but also, for example, if a discrepancy occurs between the order and shipments of items. The infrastructure would provide executives with timely and accurate information on the location, movement, status, and identity of units, personnel, equipment, material, and supplies in real-time. This would provide the executives with the capability of making changes in plans, policies, and procedures.

Supply chain process management (SCPM) employs event and performance alerts to allow supply chain parties to detect, resolve, and solve problems in real-time. For instance, RFID infrastructure triggers an event alert when a shipment has not left the supplier as scheduled and a performance event when the order fulfilment throughput has fallen below a certain threshold level. [2]

Depending on the size of RFID infrastructure and the organization, it may be feasible to split SCPM into Supply chain event management (SCeM) and Supply chain performance management (SCPM), each handling a large base of event triggers. This allows SCeM and SCpM to collect real-time data from multiple sources across multiple supply chains over heterogeneous systems. It also allows them to launch workflows and issue alerts to appropriate parties not only on the RFID infrastructure laptop screen but also via e-mail, phone, fax, personal digital assistant, or other devices.

Some vendors, however, specialize only in SCeM, whereas others have added SCeM components to their enterprise systems. Some vendors treat SCeM as one of the SCpM components. For others, SCpM is the SCeM.

\section{ECONOMIC FEASIBILITY OF ROLLING OUT RFID}

When conducting a study on economic feasibility of rolling out RFID, you must ensure that the risks have been mitigated to tolerable levels. Examples include no labour reduction, increased maintenance costs without data synchronization, inaccurate replenishment or reduction of out-of-stock, inaccurate pricing, and potential for increased transaction management costs.

Factors that should be considered in your cost/benefit analyses include

- Supply chain optimization;

- Customer privacy issues;

- Security challenges;

- Operational and IT challenges;

- Logistical challenges;

- Program management challenges;

- Education and training;

- Standard implementation challenges.

It is also important how you calculate the ROI to determine the best potential return of various investment options. To implement RFID, net value present method-based ROI (also known as the time-value ROI) is a preferred method as the cash flows will most likely fluctuate from one year to another and the RFID technology and standards continue to evolve for faster product visibility and traceability due to improved business processes that the technology brings.

In addition to cash flow fluctuations, the time-value ROI is useful when the company makes additional capital expenditures after the project has started (e. g., a pilot study project to a full production project). This type of calculation is also useful when the company invests in building a large facility to accommodate the RFID infrastructure over a period of time; that is, investments do not occur at once. The choice of investment options depends on whether the company is mandated to implement RFID technology, the sophistication of the RFID technology the company needs to implement, and the company's dependencies in a complex network of multi-suppliers (e. g., first-level suppliers depend on the second-level suppliers, and so on).

\subsection{Supply chain synchronization}

The key to global supply chain synchronization is the global open standards for interoperable RFID technologies. The standards organizations contribut- 
ing to the RFID standards are EPCglobal Inc., International Standards Organization (ISO), and the American National Standards Institute (ANSI). However, the nature of SCM networks makes the synchronization complex. The executives need to identify which players in the synchronization are leaders, challengers, or visionaries and which players are leading-edge or mainstream technology adopters.

The foundation of enabling synchronization is business process management as the basis for RFID visibility and traceability, business activity monitoring, analytics, and optimization.

\subsection{Customer privacy issues}

The costs of protecting privacy are far cheaper than the costs of lawsuits on the loss of privacy protection. One way of keeping the costs low is to develop a mechanism to deactivate the security function of the RFID tag while a self-check-out station scans the merchandise. This allows the customer to carry the merchandise outside the store even while walking in another radio frequency field generated by another RFID reader. If the tags are not properly deactivated, a war-driver can read and get the information from the RFID tags of purchased goods that a passerby carries in a shopping bag.

Let us take a look at a Gillette RFID tracking system at a Massachusetts Wal-Mart supermarket. It worked but was eventually replaced by a new version because of privacy issues. The older tracking system sensed when a product was removed from the shelf. It then took a photograph of the shopper, compared to another snap taken when the product reached the check-out. The new system excludes the photography feature.

Another privacy issue that Dixon raised is what flashes up on a scanner as someone walks near the interrogator (especially active interrogators that have a much wider scanning region that those of passive interrogators). The scanner could show:

- contents of materials;

- contents of briefcase or handbag;

- which credit cards are being carried;

- linkage to RFIDs that identify the user of passport in suit pocket.

The challenge is to ensure that the privacy issues are not overlooked and that the consumer privacy is protected when rolling out RFID technology.

\subsection{Security challenges}

War-walking is more bold than war-driving. War-walkers do not need a wireless device to find the RFID tags. With fake credentials or cards they can bypass physical checks and find the system that uses
RFID tags to monitor the movements of conference attendees.

Let us assume the cracker goes beyond finding the system. The cracker either runs away or removes the passive RFID tags from the objects, for instance, inside one. The cracker replaces them with the counterfeited tags and reattaches the tag with original RFID data to the similar objects in another case, all without being detected. This technique is known as lifting.

In another instance, a corporate spy walks around, scans the entire stock of a competing retail outlet, rewrites the tags of cheap products and replaces them with better product labels and even hides products in a metal-lined tag and replaces them with new tags on the shelf.

The challenge is to ensure that physical security is in place when rolling out RFID technology.

\subsection{Operational and IT challenges (hardware, software, system compatibility, people expertise)}

Some challenges a Chief Technology Officer (CTO) faces are that governance infrastructure of the company may not provide the IT staff with the authority and support to do their jobs. The CTO also faces the challenge of the rapid pace of technology change, inadequate funding, inadequate staffing, enterprise integration issues, and inadequate agreement on enforcement in standardization in equipment, software, procedures, and policies.

The interoperability problems among diverse platforms, software, and hardware although the interoperability standards are evolving. Added to the agenda are the lack of standards on the proximity of the antennas for active RFID technology, and the lack of standards on sharing the reading area by multi-readers, the emerging global EPCglobal standards more compatible with the ISO standards on RFID technology, and the issues of integrating unstructured data (e-mail, videos, and XML) with the RFID input reads.

\subsection{Logistical challenges}

Setting up the logistics of supply chains depends on how complex is the vertical and the horizontal supply chain integration, what business processes are used, what material management regulations the enterprise running the SCM system must comply with, and what type of enterprise the organization is. It depends on what information the customers are looking for, how fast they want the information, and how high the visibility of item movements they want.

It also depends on what material requirements the organization needs to get its SCM system to satisfy, 
such as make-to-order, engineer-to-order, make-to-stock, continuous replenishments, or seasonal replenishment. Some requirements are well suited for mass production whereas others fit into the mass customization category. The remaining portion may be a hybrid of both.

Also important is how serviceable material items to be returned should be handled for repair, overhaul, and maintenance and who should bear the costs of packing and transporting these items to the intended warehouses to accept these items for further processing.

Not to be overlooked is a model of organizational maturity. No matter how components are modularized, arranged, prioritized, and optimized, they may not work properly if the organization is not sufficiently mature to design, develop, and implement a SCM subsystem, for instance, the SCM logistics system. To test for the maturity of the organization in incorporating RFID technology infrastructure into the logistics, we divide the system into five life stages and then assess each stage if it meets certain criteria before we proceed to the higher-level stage.

- pilot studies,

- logistics projects,

- organizational operations,

- logistics visibility,

- logistics optimization.

\subsection{Program management challenges}

An enterprise should create an RFID Program Management Office (PMO) before developing RFID strategies. This office should be run by a person who can oversee the RFID selection and implementation program and have the ability to give a strategic option of building the RFID infrastructure and connect with the legacy systems via middleware platforms. This person should have the ability to integrate projects throughout the organization and achieve the desirable $\mathrm{ROI}$ in the long run. More important, a checklist of the following activities should be developed to determine the degree of involvement by the PMO to gauge the potential success of the RFID implementation program.

- RFID strategic plan for the entire organization;

- Project plan;

- Security and consumer privacy issues;

- Budget: initial, performance, and changes;

- Staffing;

- Methodologies and processes;

- Training programs;

- Funding;

- Standards;

- Risk management.
Other activities can be added as needed, such as:

- Project dependencies;

- Change management;

- Checklists for project activities;

- Constraints;

- Post implementation review;

- Configuration management and business process reengineering.

\subsection{Education and training}

There is need for education and training in RFID technology by providing C-level executives and senior managers with selection guideline criteria on:

- RFID devices and middleware to connect the RFID infrastructure with enterprise legacy systems;

- technical skills and knowledge needed for successful implementation of the technology in the areas of installation, configuration, and maintenance of RFID hardware and device software;

- site surveys and site analysis;

- tag selection, placement, and testing.

\subsection{Standard implementation challenges}

Standards are critical for many RFID applications in supply chains. Much work has been done to develop standards for different RFID frequencies and applications. RFID standards - existing and proposed - fall into these types:

- Air interface protocol: the way the tags and readers communicate;

- Data content: the way data is organized or formatted;

- Conformance: ways to test that products meet the standard;

- Applications: how standards are used on shipping labels.

The trend is toward single global standards. For instance, in the air interface protocol category, EPCglobal developed a second-generation protocol (Gen2). Gen2 was approved in December 2004. RFID vendors that had worked on the ISO UHF standard also worked on Gen2. [3]

\section{PROCESSES OF SUPPLY CHAIN MANAGEMENT}

There are five fundamental processes in supply chain management, all of which stand to be improved through the application of RFID technology: 


\subsection{Demand planning and forecasting}

Supply chain software applications use mathematical models to predict future demand from history data. These models are only as good as the input data. RFID will not only improve the accuracy of data available to the models, but the wealth of the data as well. New mathematical models will be made to make use of the new types of information that RFID systems will produce. This should result in more accurate demand forecasts.

\subsection{Procurement}

Procurement involves not only the negotiation of prices with suppliers but also the receiving and verifying of shipments. Supply chain management systems enhanced through RFID technology will help to further automate these procurement processes, thereby driving the costs of procurement down.

\subsection{Manufacturing and assembly}

RFID can be used on assembly lines to automate and streamline the manufacturing process as shown in Figure 3.
For example, RFID technology can facilitate a decentralized manufacturing process. In traditional manufacturing processes, all points along an assembly line are networked directly to a central database. As goods flow through the process, the central database has to be updated at each step along the way. This may not always be possible or cost-effective. For example, it might not be possible to network some points in the process to the central database, or it might require too much touch labour to keep track of each item in the pipe.

With RFID technology a tag can be used as a portable database. Rather than network each point in the manufacturing process to a central database, only a few points in the process need to be connected, such as the beginning and the end. As goods flow through this type of assembly line, important, item-specific information can be recorded directly on the tag. The information would then travel with the item, rather than reside at the central database. Figure 3.1 shows the flow of information in a decentralized versus a centralized computer control system. [4]

To illustrate how the decentralized manufacturing process would work in the real world consider how a company like Dell Computer might use it. Dell Computer makes PCs to order. When an order is made, the production process begins. Dell allows its customers

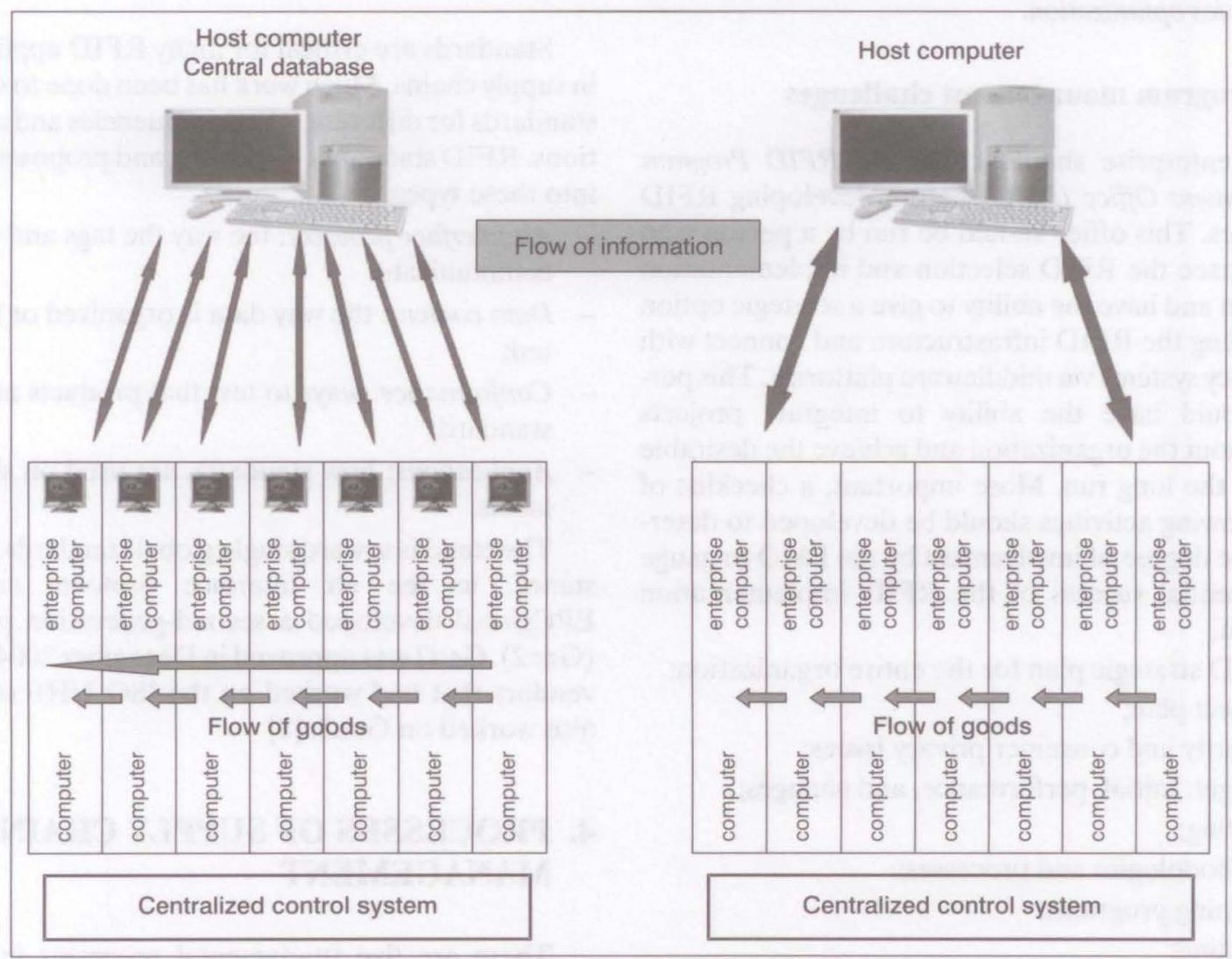

Figure 3 - Decentralized vs. centralized manufacturing 
to choose between a number of options and features when buying their computers, such as processor speed, amount of memory, hard disk size, etc. In a decentralized manufacturing process, all of this configuration information could be written to an RFID tag on an empty case. The empty case would then enter the production process, at which time the central database, which ultimately keeps track of the order, would effectively lose sight of it.

As the case moves through the assembly line, presumably on a conveyor belt, the components would be added as directed by the configuration list and then checked off on the tag as having been installed. At times, the case might come to a junction where computers that need modems are directed left while those that do not are directed right. An RFID render installed at this point could check the configuration information on the tag and direct the case to the proper point. Eventually, a complete computer, packed inside a box and addressed to the customer that ordered it, would exit the manufacturing process. Assuming this point of the process is networked to the central IT system, the central database could be updated and the distribution process could begin.

\subsection{Distribution}

Distribution is that portion of the supply chain process where products are delivered to customers and it includes warehousing, delivering, invoicing, and payment collection. By automating these processes through the use of RFID, distribution can be made more efficient.

Figures 4, 5, and 6 illustrate how RFID technology could automate various steps in the distribution process. Figure 4 depicts a factory, in this case a pharmaceutical factory. Each item contains an RFID tag. Inside the plant, items can be automatically identified, counted, and tracked. As product leaves the plant, an RFID reader installed in the dock doom checks the contents of the shipment and updates inventories accordingly. [5]

Figure 5 depicts a distribution centre. When the shipment arrives in the unloading area, RFID readers at the doors examine its contents and update inventories accordingly. The manufacturer can be notified automatically that the shipment has been received and the pallet can quickly be routed to the appropriate delivery truck or to its proper place in the warehouse, all without the need to open packages or examine their contents.

When the shipment arrives at the retail store (Figure 6), the inventory systems are updated to include every item. Furthermore, RFID-enabled "smart" shelves can automatically order more products from the manufacturer when the inventory runs low. This

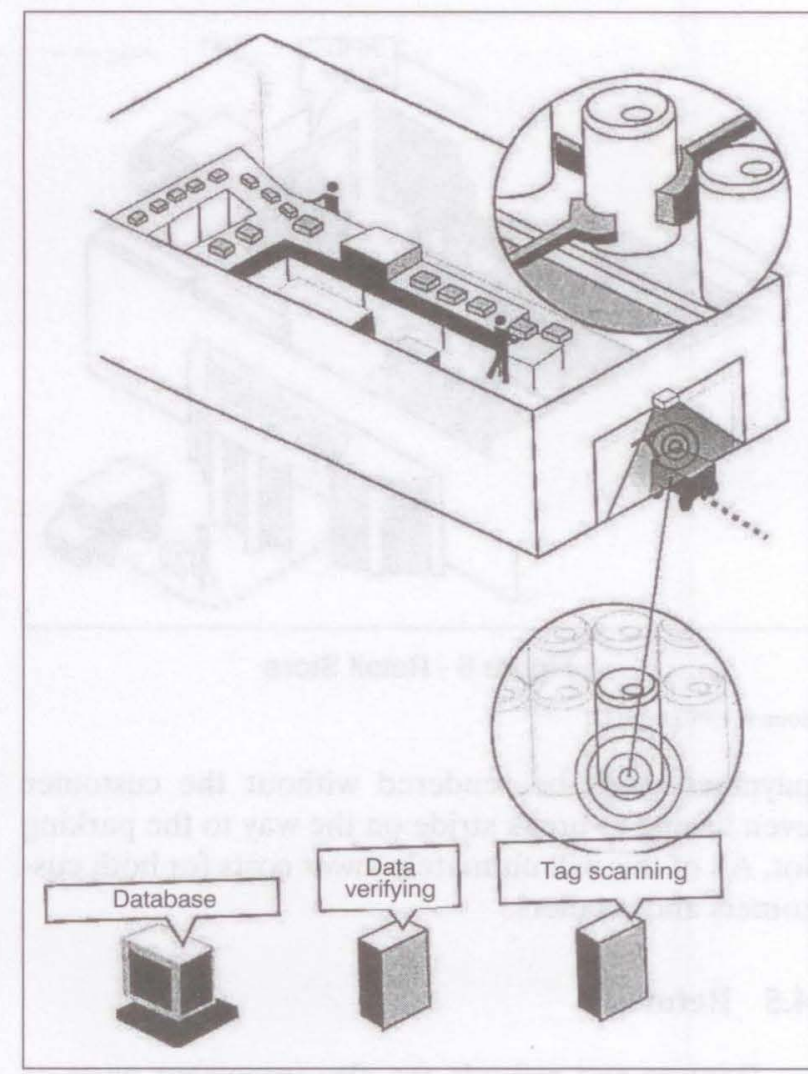

Figure 4 - Product leaves the manufacturer

Source: EPCglobal [2]

will help to keep stocks at efficient levels. In the future, customers will be able to purchase their items without waiting in check-out line. RFID readers installed at the exits will automatically identify the contents of a customer's basket. Payment could be made without an employee ever having checked the basket, and, in fact, with RFID-enabled payment systems,

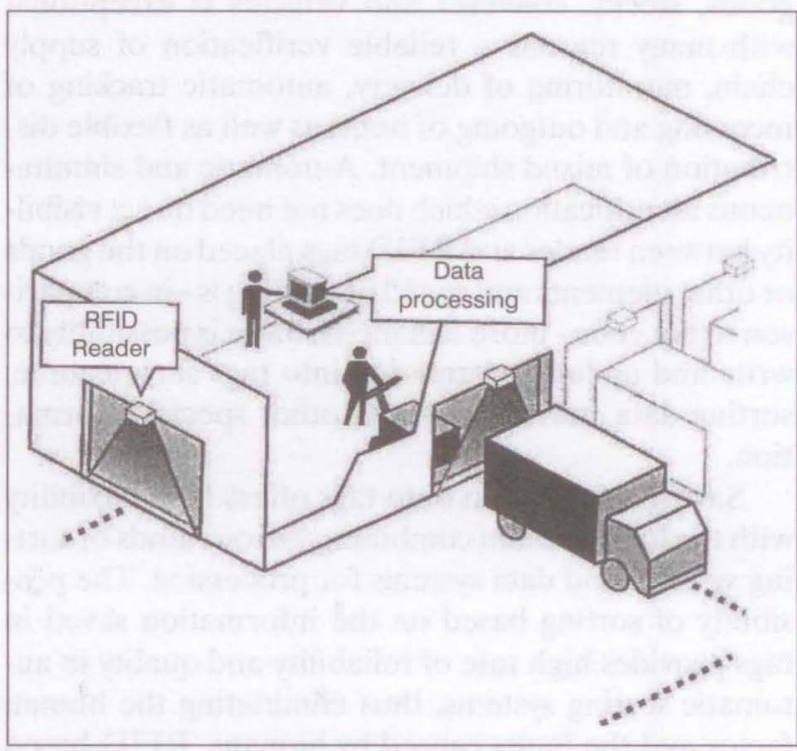

Figure 5 - Distribution centre

Source: EPCglobal [2] 


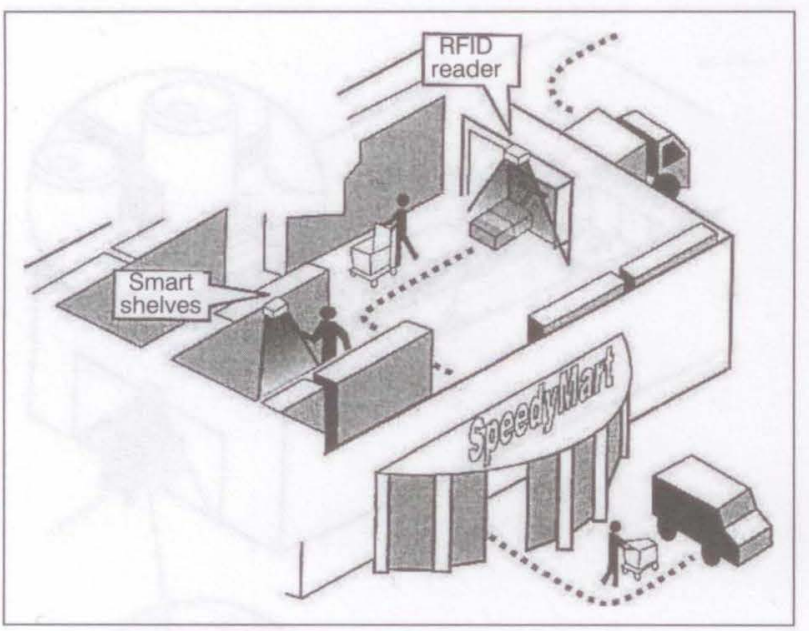

Figure 6 - Retail Store

Source: EPCglobal [2]

payment could be rendered without the customer even having to break stride on the way to the parking lot. All of this will ultimately lower costs for both customers and retailers.

\subsection{Returns}

Returns and refunds are also important parts of supply chain management. RFID can be used to direct defective merchandise back to the manufacturer and more quickly process returns, credit accounts, etc. By automating these processes through RFID the costs of returns can be reduced.

\section{CONCLUSION}

RFID technology and automatic reorganization of goods, stocks, conveyer and vehicles is exceptional with many reasons - reliable verification of supply chain, monitoring of delivery, automatic tracking of incoming and outgoing of items as well as flexible distribution of mixed shipment. Automatic and simultaneous identification which does not need direct visibility between reader and RFID tags placed on the goods or other elements and speed of reading is - in comparison to bar code - more enhanced, there is possibility to write and update information into tags such as time, sorting data, cartage line and other special information.

Saving information onto tags offers high flexibility with the logistic chain combining various kinds of sorting systems and data systems for processing. The possibility of sorting based on the information saved in tags provides high rate of reliability and quality in automatic sorting systems, thus eliminating the human factor and the faults caused by humans. RFID-based systems yield very good reports and reviews of logistic chains and consequently, without any problems among people who take care about transport and sorting - who incurred instability in the logistic chain and the quality for customers has to be the aim of the logistics system as well as the supply chain management.

Doc. Ing. JURAJ VACULÍK, Ph.D.

E-mail: juvac@fpedas.uniza.sk

Ivan Michálek, ing.

E-mail:imichalek@centrum.sk

PETER KOLAROVSZKI, ing.

E-mail: kolarovszki@fpedas.uniza.sk

Žilinská univerzita, Fakulta prevádzky a ekonomiky dopravy a spojov

Katedra spojov

Univerzitná 1, 01026 Žilina, Slovenská republika

\section{ABSTRAKT}

\section{ZÁSADY SELEKCE, IMPLEMENTACE A VYUŽITÍ RFID TECHNOLOGIE V PROSTŘEDÍ SUPPLY CHAIN MANAŽMENTU}

Tenhle článek sa zaobírá implementaci a využitím RFID technologie v prostředí supply chain manažmentu a je v něm také zahrnuta analýza ekonomické př́pustnosti rozvoje RFID technologie. Členové logistického řetězce - dodávatelé, výrobci a distribútori pusobi nezávisle jeden od druhého a na tomto základě přispúsobí $i$ své programy. Tento druh neřizené sítě sa nakonec projevuje jako neefektívní. Výrobce má za cíl maximalizaci výroby při minimalizaci jednotkových nákladu. Všeobecně je tedy duležité, aby každý účastník logistického retězce usiloval o dosáhnutí potřebnej koordinace s cílem zvýšení efektivity a celkového výkonu řetězce. Článek je segmentován na 3 kapitoly : Logistický řetězec, ekonomická př́pustnost rozvoje RFID a procesy v supply chain manažmentu.

\section{KLÍČOVÉ SLOVÁ}

RFID (rádio frekvenční identifikace), supply chain manažment, procesy, implementace

\section{LITERATURE}

[1] Judith M. Myerson, RFID in the Supply Chain: A Guide to Selection and Implementation, ISBN 978-08493301086, 2007

[2] V. D. Hunt, A. Puglia, M. Puglia, RFID: A Guide to Radio Frequency Identification, ISBN 970470107645 2007

[3] Poirier Charles, RFID Strategic Implementation and ROI : A Practical Roadmap to Success, ISBN 1-932159-47-9, J. Ross Publishing, Inc. 2006

[4] Vaculík Juraj. a kol. : Telematické služby II, vysokoškolská učebnica, EDIS 2007, ISBN 978-80-8070-690-6,

[5] Šulgan Marián: Pilotný projekt logistického parku v regióne Žilina. Medzinárodná konferencia Dopravná infraštruktúra v mestách. Žilina, 6. - 7. 12. 2006, str. 109-113. Vydal EDIS- vydavatelstvo ŽU Žilina 2006. ISBN 80-8070-621-2.

[6] Internet source: www.zebra.com 